\title{
Compensatory nitrogen retention in growing pigs following a period of $\mathbf{N}$ deprivation
}

\author{
BY J. BRONWYN TULLIS AND C. T. WHITTEMORE* \\ Department of Agriculture, University of Edinburgh, \\ West Mains Road, Edinburgh EH9 $3 J G$ \\ AND PATRICIA PHILLIPS \\ AFRC Unit of Statistics, Kings Buildings, \\ Mayfield Road, Edinburgh EH9 $3 \mathrm{JZ}$
}

(Received 9 October 1985 - Accepted 10 February 1986)

\begin{abstract}
1. Semi-synthetic diets, with dried microbial cells (Pruteen) as the nitrogen source, were used to measure $\mathrm{N}$ retention in $50 \mathrm{~kg}$ pigs given different combinations of $\mathrm{N}$ intake involving periods of deprivation and enhanced supply.

2. Metabolic faecal $\mathrm{N}$ losses were $1.92 \mathrm{~g} / \mathrm{d}(1.26 \mathrm{~g} / \mathrm{kg}$ dry matter eaten) and endogenous urinary losses were $3.96 \mathrm{~g} / \mathrm{d}$ for pigs given an $\mathrm{N}$ intake of $6.9 \mathrm{~g} / \mathrm{d}$.

3. Compensatory $N$ retention averaging $4 \cdot 2$ extra $N / d$ was observed in pigs given enhanced $N$ supply by diets providing $31 \cdot 0,60.4$ and $93.4 \mathrm{~g} \mathrm{~N} / \mathrm{d}$. In some instances enhanced $\mathrm{N}$ retention was maintained for $22 \mathrm{~d}$.

4. Pigs given enhanced $\mathrm{N}$ supply by extravagant $\mathrm{N}$ intake did not maintain the compensatory response which had been evident initially.
\end{abstract}

Many pigs undergo a period of growth during which deposition of protein proceeds at below the potential rate; for example, as a result of depressed feed intake following weaning or as a consequence of imperfect matching of dietary protein supply to protein requirements for growth. It is therefore of biological and economic importance to ascertain whether or not pigs can compensate for a temporary reduction in protein deposition rate by undergoing a period of enhanced nitrogen retention when dietary protein supply is more liberal. A previous paper (Whittemore et al. 1978) demonstrated that compensatory protein retention (as measured by $\mathrm{N}$ balance) was possible in growing pigs following a $12 \mathrm{~d}$ period of $\mathrm{N}$ deprivation, and that enhanced $\mathrm{N}$ retention rates were associated with improved efficiency of utilization of dietary $N$. The aim of the present experiment was to examine the phenomenon in more detail by providing growing pigs with a sequence of three diets. The four diets used contained low, medium, high or extravagant levels of protein, and they were offered in combinations to test the effects of changes on $\mathrm{N}$ balance during the first three and the following $7 \mathrm{~d}$. These were compared with values obtained from control pigs which received one of the four diets throughout the experiment. It was also of interest to examine possible changes in the biological value of proteins when provided at different levels in the diet.

Conventional balance techniques were used to measure $\mathrm{N}$ balance after profound changes in $\mathrm{N}$ intake. Control treatments involved the provision of very low, moderate, high and very high daily $\mathrm{N}$ intakes, the very high level being included to test $\mathrm{N}$-retention response at an extreme level of $\mathrm{N}$ supply. While compensatory $\mathrm{N}$ retention was observed, the results indicated that this mechanism accords more closely with the short-term replenishment of variable body lean (Fowler, 1976) or labile N stores (Boorman, 1980), than the acceleration of $\mathrm{N}$ deposition in carcass muscle growth to allow growing pigs to compensate for previous dietary misfortunes and catch up with unchecked contemporaries. 
EXPERIMENTAL

Diets

Four semi-synthetic diets, low-protein (LP), medium-protein (MP), high-protein (HP) and very high (extravagant)-protein (EP), were compounded from the ingredients whose composition is shown in Table 1. The protein source was dried microbial cells (Pruteen; ICI Ltd (Agricultural Division), Billingham, Cleveland; DMC), a flash-dried product of the culture of Methylophilus methylotrophus on methanol. Ingredients were compounded in the proportions indicated in Table 2 to form the four diets; differing $\mathrm{N}$ contents were obtained for each diet by altering the proportions of DMC relative to maize starch. Determined $N$ contents were $4.47,20 \cdot 35,39.49$ and $61.15 \mathrm{~g} / \mathrm{kg}$ dry matter (DM) for diets LP, MP, HP and EP respectively. All diets were given at the rate of $875 \mathrm{~g}$ twice daily together with 1.75 litres of water at each feed. Daily intakes of DM, gross energy (GE) and $N$ are presented in Table 3. There were some feed refusals by pigs offered diet LP, which was formulated to maintain the animals in $\mathrm{N}$ equilibrium.

\section{Procedures}

Forty-eight Large White barrows of 51.2 (SD 7.96) kg live weight were used for conventional $\mathrm{N}$-balance determinations using metabolism crates which allowed quatitative feeding and separate collection of faeces and urine. There were twelve pigs in each of four replicates; allocation to replicate was by pig availability, and incidentally resulted in heavier pigs in replicates 1 and 2 (initial live weight $57.6(\mathrm{SE} 0.88) \mathrm{kg}$ ) than in replicates 3 and 4 (initial live weight 44.8 (SE 1.15 ) kg). Bulk 3,7 and $10 \mathrm{~d}$ collections of excreta were preserved at $\mathrm{pH} 4 \cdot 5-5 \cdot 5$ (faeces) and 2-3 (urine) by addition of dilute sulphuric acid. Subsamples were analysed for $\mathrm{N}$ by Kjeldahl digestion and for GE by adiabatic bomb calorimetry.

All pigs were given diet MP for $3 \mathrm{~d}$ before a $7 \mathrm{~d}$ prefeeding period on the diet to be offered during the first balance period. The sequence of dietary treatments is shown in Table 4. There were four pigs on each dietary sequence (one pig/dietary sequence per replicate). There were three periods, each of $10 \mathrm{~d}$; periods 2 and 3 were subdivided into $3 \mathrm{~d}(2 \mathrm{~A}, 3 \mathrm{~A})$ and $7 \mathrm{~d}(2 \mathrm{~B}, 3 \mathrm{~B})$ balances in order to monitor short- and longer-term responses to change in dietary $\mathrm{N}$ level. No excreta were collected for $24 \mathrm{~h}$ following a diet change-over (days 18 and 29 of the experiment).

\section{RESULTS}

Daily $\mathrm{N}$ losses by pigs given diet LP (period 1, twenty-four pigs; periods $2 \mathrm{~B}$ and $3 \mathrm{~B}$, three pigs each) were regarded as measurements of metabolic faecal $N$ (MFN) and endogenous urinary $\mathrm{N}$ (EUN) and are detailed in Table 5. Mean daily $\mathrm{N}$ losses over the three balance periods were $1.92 \mathrm{~g} \mathrm{MFN} \mathrm{(1.26} \mathrm{g} \mathrm{N/} \mathrm{kg} \mathrm{DM}$ consumed) and $3.96 \mathrm{~g}$ EUN. There was no significant difference in MFN between periods or between replicates. EUN did not alter significantly between periods but was higher for heavier pigs in replicates 1 and 2 $(4.95 \mathrm{~g} \mathrm{~N} / \mathrm{d})$ than for the lighter pigs in replicates 3 and $4(2.83 \mathrm{~g} \mathrm{~N} / \mathrm{d} ; P<0.001)$.

Table 6 gives $N$ balance and digestibilities of GE and $N$ in period 1 (days 8-17 of the trial) for pigs given diets LP, MP, HP and EP. The mean $\mathrm{N}$ retention obtained for pigs given diet LP of 0.95 (SE 0.834$) \mathrm{g} / \mathrm{d}$ indicated them to have been in $\mathrm{N}$ balance. The response in $\mathrm{N}$ retention to increasing $\mathrm{N}$ intake was such that the highest level of $\mathrm{N}$ intake (diet $\mathrm{EP}$, $93.4 \mathrm{~g} \mathrm{~N} / \mathrm{d}$ ) did not show that a maximum rate of $\mathrm{N}$ retention had been reached with diet HP. Digestibility of the DM declined with increasing $N$ content of the diet: mean values were $0.93,0.93,0.91$ and 0.89 for diets LP, MP, HP and EP respectively. The biological value of the DMC-protein source (denoting the method of calculation rather than, in the strict sense of the term, a measurement confined to protein-limiting circumstances) declined 
Table 1. Chemical composition of dietary ingredients $(\mathrm{g} / \mathrm{kg}$ dry matter $(D M))$

\begin{tabular}{|c|c|c|c|c|c|c|}
\hline Ingredient & $\begin{array}{c}\text { DM } \\
(\mathrm{g} / \mathrm{kg})\end{array}$ & $\begin{array}{c}\text { Gross } \\
\text { energy } \\
\text { (MJ/kg } \\
\text { DM) }\end{array}$ & Nitrogen & Fat & Fibre & Ash \\
\hline Dried microbial cells* & 893 & $22 \cdot 57$ & $122 \cdot 5$ & $86 \cdot 0$ & $16 \cdot 4$ & $88 \cdot 19$ \\
\hline Maize starch & 864 & $18 \cdot 08$ & $0 \cdot 50$ & $0 \cdot 81$ & $5 \cdot 6$ & 1.51 \\
\hline Sucrose & 999 & $16 \cdot 40$ & $0 \cdot 17$ & $2 \cdot 00$ & $4 \cdot 0$ & 0.36 \\
\hline Glucose & 911 & $15 \cdot 52$ & $0 \cdot 17$ & $2 \cdot 40$ & $2 \cdot 8$ & 0.64 \\
\hline Cellulose $†$ & 936 & $17 \cdot 24$ & $0 \cdot 21$ & 0.0 & $35 \cdot 2$ & $4 \cdot 24$ \\
\hline Maize oil & 0 & $39 \cdot 70$ & 0.0 & $99 \cdot 2$ & 0.0 & $0 \cdot 0$ \\
\hline Mineral and vitamin mixturef & 910 & - & 1.82 & $3 \cdot 60$ & $4 \cdot 8$ & $895 \cdot 55$ \\
\hline
\end{tabular}

* Pruteen; ICI Ltd (Agricultural Division), Billingham, Cleveland.

$\uparrow$ Solkafloc; Johnson, Jorgenson and Wettre Ltd, London EC4M 7HA.

\$ 1065C; Vitriton Ltd, Stamford, Lincs PE9 2RA. To supply (/kg diet): calcium $11.8 \mathrm{~g}$, phosphorus $8.0 \mathrm{~g}$, sodium chloride $5.0 \mathrm{~g}$, potassium $5.0 \mathrm{~g}$, magnesium $400 \mathrm{mg}$, iron $60 \mathrm{mg}$, zinc $60 \mathrm{mg}$, manganese $20 \mathrm{mg}$, copper $10 \mathrm{mg}$, cobalt $0.5 \mathrm{mg}$, iodine $0.8 \mathrm{mg}$, thiamin $4.0 \mathrm{mg}$, riboflavin $5.0 \mathrm{mg}$, nicotinamide $30.0 \mathrm{mg}$, pantothenic acid $10.0 \mathrm{mg}$, pyridoxine $2.5 \mathrm{mg}$, pteroylmonoglutamic acid $2.0 \mathrm{mg}$, choline $1000 \mathrm{mg}$, cyanocobalamin $2.0 \mu \mathrm{g}$, retinol $901 \mu \mathrm{g}$, biotin $200 \mu \mathrm{g}$, cholecalciferol $25.0 \mu \mathrm{g}, \mathrm{D}-\alpha$-tocopherol $10.0 \mathrm{mg}$, menaphthone $120 \mu \mathrm{g}$, butylated hydroxytoluene $0.125 \mathrm{~g}$.

Table 2. Ingredients and chemical composition of experimental diets $(\mathrm{g} / \mathrm{kg}$ fresh weight)

\begin{tabular}{lcccc}
\hline Diet... & LP & MP & HP & EP \\
\hline Ingredient & & & & \\
$\quad$ Dried microbial cells* & 27 & 150 & 350 & 450 \\
Maize starch & 723 & 600 & 400 & 300 \\
Sucrose & 50 & 50 & 50 & 50 \\
Glucose & 50 & 50 & 50 & 30 \\
Cellulose & 30 & 30 & 30 & 50 \\
Maize oil & 50 & 50 & 50 & 70 \\
Mineral and vitamin mixture $\dagger$ & 70 & 70 & 70 & $872 \cdot 6$ \\
Chemical composition & & & & $19 \cdot 30$ \\
Dry matter (DM; g/kg) & $870 \cdot 9$ & $871 \cdot 4$ & $872 \cdot 0$ & $61 \cdot 15$ \\
Gross energy (MJ/kg DM) & $16 \cdot 66$ & $17 \cdot 88$ & $18 \cdot 57$ & $39 \cdot 49$ \\
Nitrogen (g/kg DM) & $4 \cdot 47$ & $20 \cdot 35$ & & \\
\hline
\end{tabular}

* Pruteen; ICI Ltd (Agricultural Division), Billingham, Cleveland.

$\dagger$ For details see Table 1.

Table 3. Daily intakes of dry matter $(D M)$, gross energy $(G E)$ and nitrogen by pigs given experimental diets of differing nitrogen content (low (LP)-, medium (MP)-, high (HP)- and very high (EP)-protein)

\begin{tabular}{lccrr}
\hline Diet... & LP & MP & HP & EP \\
\hline Fresh wt (g/d) & 1750 & 1750 & 1750 & 1750 \\
DM (g/d) & 1524 & 1525 & 1526 & 1527 \\
GE (MJ/d) & $25 \cdot 6$ & $27 \cdot 3$ & $28 \cdot 3$ & $29 \cdot 5$ \\
N $(\mathrm{g} / \mathrm{d})$ & 6.9 & $31 \cdot 0$ & $60 \cdot 4$ & $93 \cdot 4$ \\
\hline
\end{tabular}


Table 4. Design of experiment to determine the effect of feeding different sequences of diets of differing nitrogen content (low (LP)-, medium (MP)-, high (HP)- and very high (EP)-protein) to growing pigs

\begin{tabular}{cccccccc}
\hline \multirow{2}{*}{$\begin{array}{c}\text { Day of } \\
\text { experiment }\end{array}$} & Period & \multicolumn{7}{c}{ Dietary sequence* } \\
\cline { 3 - 8 } & LP-LP-LP & MP-MP-MP & HP-HP-HP & EP-EP-EP & LP-MP-MP & LP-MP-LP \\
\hline $1-7$ & - & LP & MP & HP & EP & LP & LP \\
$8-17$ & 1 & LP & MP & HP & EP & LP & LP \\
18 & - & LP & MP & HP & EP & MP & MP \\
$19-21$ & 2 A & LP & MP & HP & EP & MP & MP \\
$22-28$ & 2B & LP & MP & HP & EP & MP & MP \\
29 & - & LP & MP & HP & EP & MP & LP \\
$30-32$ & 3A & LP & MP & HP & EP & MP & LP \\
$33-39$ & 3 B & LP & MP & HP & EP & MP & LP \\
& & & & Dietary sequence* & & \\
Day of & & & & & & & \\
experiment & Period & LP-HP-HP & LP-HP-LP & LP-EP-EP & MP-LP-MP & HP-LP-HP & MP-HP-HP \\
\hline $1-7$ & - & LP & LP & LP & MP & HP & MP \\
$8-17$ & 1 & LP & LP & LP & MP & HP & MP \\
18 & - & HP & HP & EP & LP & LP & HP \\
$19-21$ & 2A & HP & HP & EP & LP & LP & HP \\
$22-28$ & 2B & HP & HP & EP & LP & LP & HP \\
29 & - & HP & LP & EP & MP & HP & HP \\
$30-32$ & 3A & HP & LP & EP & MP & HP & HP \\
$33-39$ & 3B & HP & LP & EP & MP & HP & HP \\
\hline \hline
\end{tabular}

* There were four pigs per dietary sequence.

Table 5. Metabolic faecal nitrogen $(M F N)$ and endogenous urinary $N(E U N)$ losses in periods $1,2 B$ and $3 \mathrm{~B}$ for pigs given the low-protein $(\mathrm{LP})$ diet (containing $4.5 \mathrm{~g} \mathrm{~N} / \mathrm{kg}$ dry matter)

\begin{tabular}{|c|c|c|c|c|c|}
\hline & \multirow{2}{*}{\multicolumn{3}{|c|}{ Period }} & \multicolumn{2}{|c|}{$S E$ of means } \\
\hline & & & & & Periods \\
\hline & 1 & $2 \mathrm{~B}$ & $3 \mathrm{~B}$ & Period 1 & $2 \mathrm{~B}$ and $3 \mathrm{~B}$ \\
\hline$n$ & 24 & 3 & 3 & & \\
\hline MFN & 1.90 & 2.01 & 2.01 & $0 \cdot 113$ & 0.321 \\
\hline EUN & 3.98 & 3.97 & 3.79 & 0.280 & 0.480 \\
\hline
\end{tabular}

with increasing $\mathbf{N}$ content of the diet. Efficiency of $\mathbf{N}$ utilization was greatest for pigs given diet MP (0.61). Apparent $\mathrm{N}$ digestibility ( $\mathrm{N}$ intake - faecal $\mathrm{N}) / \mathrm{N}$ intake) of diet LP was low, presumably because of its high content of MFN relative to dietary $\mathrm{N}$ intake; determination of the true $\mathrm{N}$ digestibility $((\mathrm{N}$ intake $-($ faecal $\mathrm{N}-\mathrm{MFN})) / \mathrm{N}$ intake showed the $\mathbf{N}$ from all four diets to be equally efficiently absorbed.

Daily live-weight gains (kg) over the $32 \mathrm{~d}$ confinement in metabolism crates were 0.404 , $0.607,0.624$ and 0.686 for pigs given diets LP, MP, HP and EP throughout (dietary sequences LP-LP-LP, MP-MP-MP, HP-HP-HP and EP-EP-EP respectively).

$\mathrm{N}$ balance in periods $2 \mathrm{~A}$ and $2 \mathrm{~B}$ (days $19-21$ and $22-28$ of the trial) is shown in Table 7. There was no significant residual effect of the dietary treatment given in period 1 . There were again significant differences between diets, reflecting the response already noted from 
Table 6. Nitrogen balance and digestibility of gross energy $(G E)$ and $N$ in period 1 (days 8-17 of the experiment) for pigs given low (LP)-, medium $(M P)$-, high $(H P)$-or very high $(E P)$-protein diets containing $4 \cdot 5,20 \cdot 3,39 \cdot 5$ and $61.1 \mathrm{~g} \mathrm{~N} / \mathrm{kg}$ dry matter respectively

\begin{tabular}{|c|c|c|c|c|c|c|}
\hline $\begin{array}{l}\text { Diet... } \\
n \ldots\end{array}$ & $\begin{array}{l}\text { LP } \\
24\end{array}$ & $\begin{array}{c}\text { MP } \\
12\end{array}$ & $\begin{array}{c}\text { HP } \\
8\end{array}$ & $\begin{array}{c}\text { EP } \\
4\end{array}$ & $\begin{array}{c}\text { Residual } \\
\text { SD } \\
(41 \mathrm{df}) \dagger\end{array}$ & $\begin{array}{c}\text { Statistical } \\
\text { significance } \\
\text { from analysis } \\
\text { of variance }\end{array}$ \\
\hline $\mathrm{N}$ retention $(\mathrm{g} / \mathrm{d})$ & 0.95 & $17 \cdot 28$ & 23.83 & $32 \cdot 36$ & 4.088 & $* * *$ \\
\hline $\mathrm{N}$ retained digested $\mathbf{N}$ & 0.18 & 0.61 & 0.42 & 0.37 & $0 \cdot 200$ & $* * *$ \\
\hline Biological value & $1 \cdot 01$ & 0.77 & 0.51 & 0.43 & $0 \cdot 154$ & $* * *$ \\
\hline \multicolumn{7}{|l|}{ Digestibility } \\
\hline GE (apparent) & 0.94 & 0.95 & 0.94 & 0.92 & $0 \cdot 021$ & NS \\
\hline $\mathrm{N}$ (apparent) & 0.72 & 0.91 & 0.93 & 0.93 & $0 \cdot 070$ & $* * *$ \\
\hline $\mathrm{N}$ (true) & 1.01 & 0.98 & 0.96 & 0.95 & $0 \cdot 063$ & NS \\
\hline
\end{tabular}

NS, not significant.

*** $P<0.001$.

$\dagger$ Standard error of mean is residual $\mathrm{SD} / \sqrt{ } n$; standard error of difference of two means is residual $\mathrm{SD} / \sqrt{ }\left[\left(1 / n_{1}\right)+\left(1 / n_{2}\right)\right]$. $\ddagger \frac{N \text { intake }-(\text { faecal } N-M F N)-(\text { urinary } N-E U N)}{N \text { intake }-(\text { faecal } N-M F N)}$

where MFN is metabolic faecal $N$, EUN is endogenous urinary $\mathrm{N}$.

Table 6. There was no significant difference in $\mathrm{N}$ balance within dietary sequences between balance periods $2 \mathrm{~A}$ and $2 \mathrm{~B}$, indicating that adjustment to the new level of $\mathrm{N}$ intake was accomplished during the $24 \mathrm{~h}$ period allowed between period 1 and period $2 \mathrm{~A}$ (day 18 of the trial).

Compensatory $\mathrm{N}$ retention may be judged to have occurred if a significant difference arises between sequences tested (Table 7). Mean $\mathrm{N}$ retention values in period $2 \mathrm{~B}$ demonstrated enhanced retentions by pigs changed from low or moderate $\mathbf{N}$ intakes to higher $\mathbf{N}$ intake at the end of period 1 relative to retentions achieved by control pigs maintained on the equivalent $\mathrm{N}$ intake in both periods. For example, the mean $\mathrm{N}$ retention by pigs given diet HP in period 2 B following diet LP or MP in period 1 was significantly higher than for pigs given diet HP throughout (sequences LP-HP-HP, LP-HP-LP and MP-HP-HP as compared with HP-HP-HP). However, the interaction of treatment $\times$ replicate prevented other improved retentions over controls reaching significance.

$\mathrm{N}$ balance in periods $3 \mathrm{~A}$ and $3 \mathrm{~B}$ (days 30-32 and 33-39 of the trial) is shown in Table 8 . The close agreement between $\mathrm{N}$ balance values for periods $3 \mathrm{~A}$ and $3 \mathrm{~B}$ (with the exceptions of diet sequences LP-HP-HP and HP-LP-HP) corroborates the observation made in period 2 that the time-interval required for adjustment following a change in $\mathrm{N}$ intake level was usually short. As for period 2 , in period 3 pigs given enhanced $\mathrm{N}$ supply after a period on a low- $\mathrm{N}$ supply showed elevated rates of $\mathrm{N}$ retention over control animals given the enhanced supply throughout. In the case of diet sequences LP-HP-HP and HP-LP-HP, as compared with $\mathrm{HP}-\mathrm{HP}-\mathrm{HP}$, these differences were significant.

\section{DISCUSSION}

The biological value of 0.63 (mean of diets MP and HP) measured for the DMC-protein source was similar to values of 0.68 (D'Mello et al. 1976) and 0.64 (Whittemore et al. 1978) obtained with growing pigs.

The estimate for MFN of $1.26 \mathrm{~g} \mathrm{~N} / \mathrm{kg} \mathrm{DM}$ consumed was identical to that found by D'Mello et al. (1976) in response to a protein-free diet. Both estimates exceed the values. 


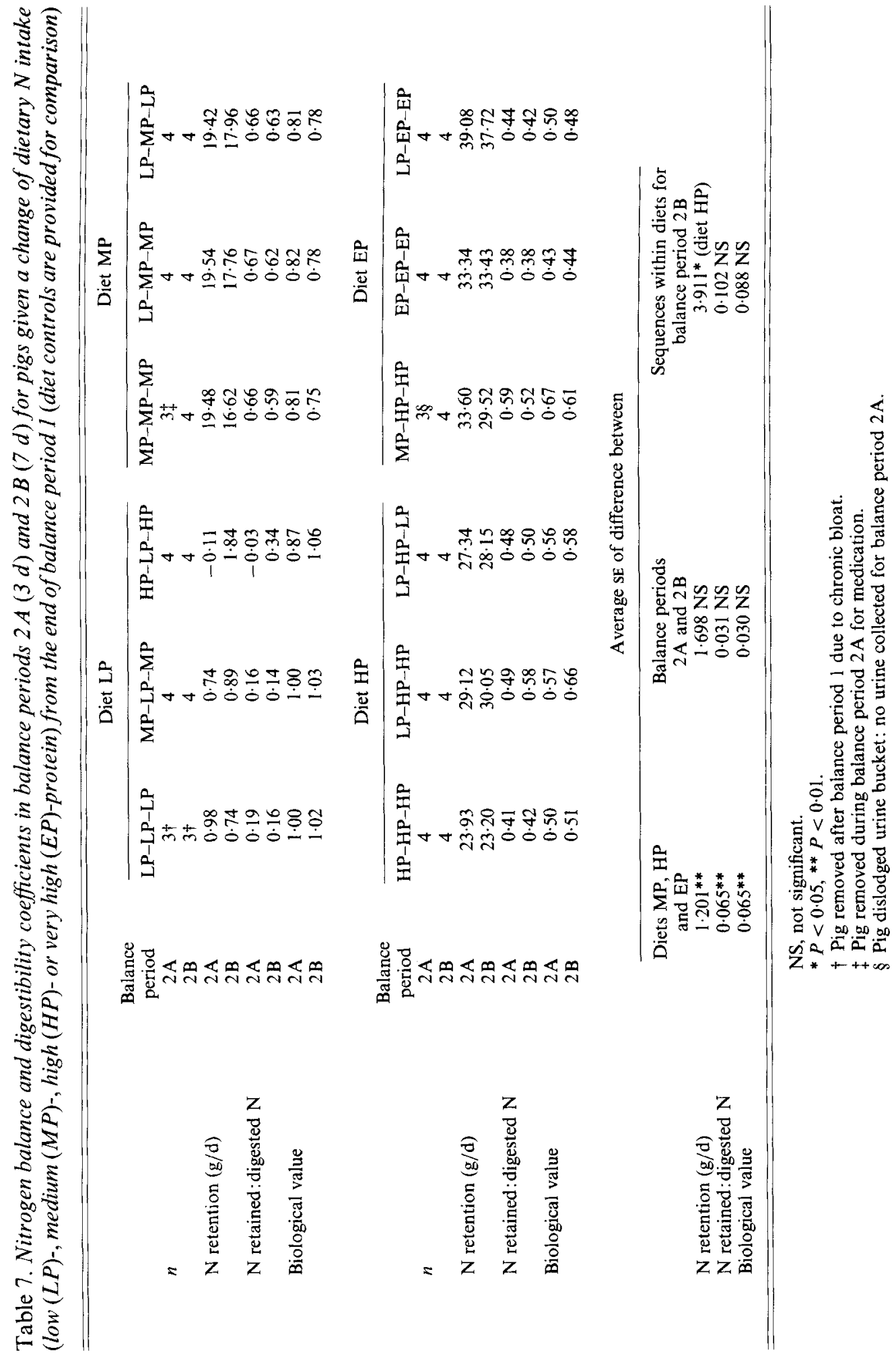


Compensatory $N$ retention in growing pigs
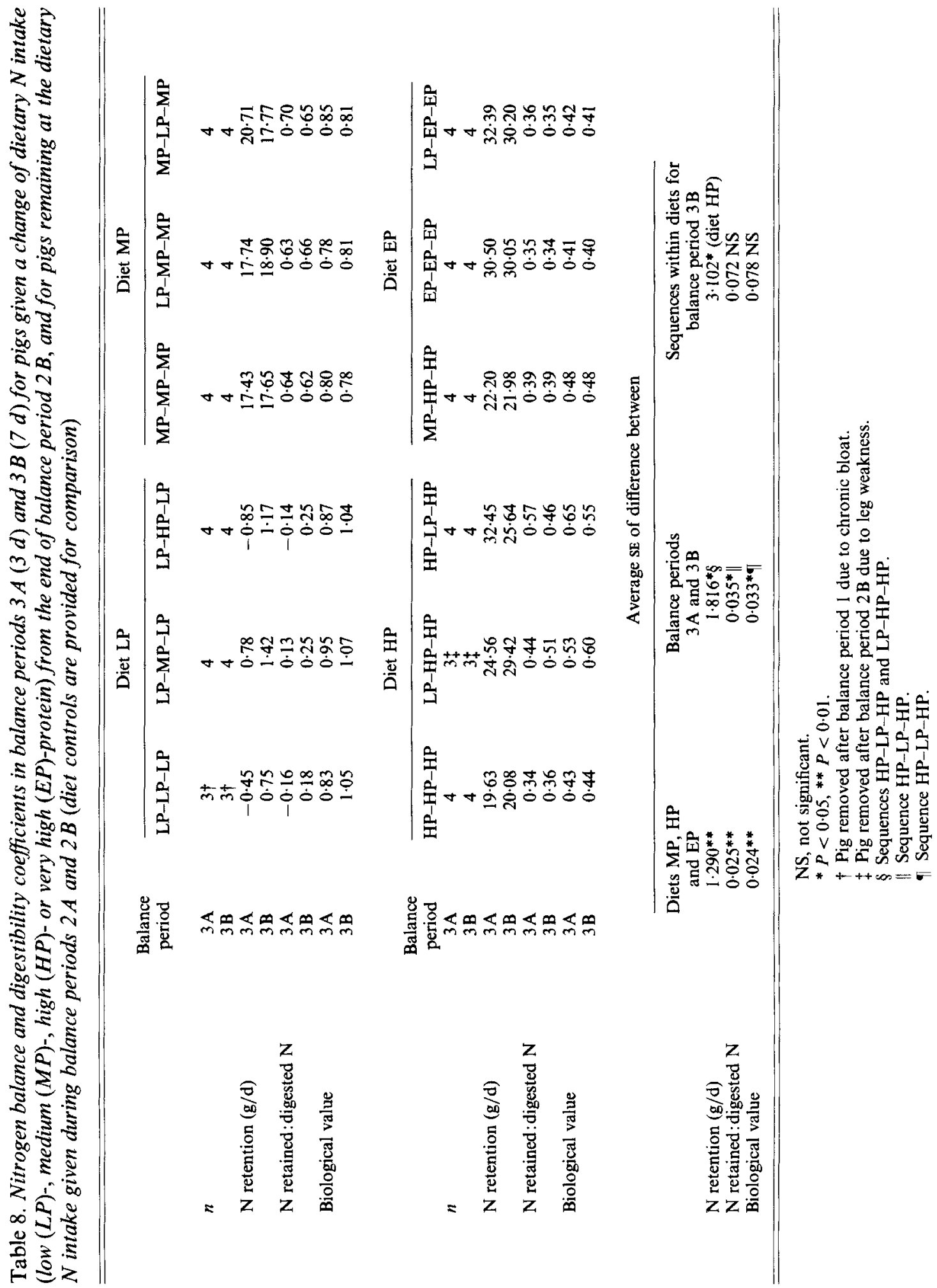


\section{J. Bronwyn Tullis, C. T. Whittemore and Patricia Phillips}

of $1 \cdot 14$ (Armstrong \& Mitchell, 1955) and 1·10 (Whiting \& Bezeau, 1957) obtained using protein-deficient diets. Total obligatory $\mathrm{N}$ loss for pigs given diet LP (daily $\mathrm{N}$ intake $6.9 \mathrm{~g}$ ) was $5.88 \mathrm{~g} / \mathrm{d}$ or $282.7 \mathrm{mg} \mathrm{N} / \mathrm{kg}$ body-weight $(\mathrm{W})^{\mathbf{0}}{ }^{75}$ per $\mathrm{d}$, in close agreement with total obligatory $\mathrm{N}$ losses by pigs of similar weight and $\mathrm{N}$ intake: $300.4 \mathrm{mg} \mathrm{N} / \mathrm{kg} \mathrm{W}^{0.75}$ per d, N intake $6.5 \mathrm{~g} / \mathrm{d}$ (Armstrong \& Mitchell, 1955) and $283.1 \mathrm{mg} \mathrm{N} / \mathrm{kg} \mathrm{W}^{0.75}$ per $\mathrm{d}, \mathrm{N}$ intake $5.4 \mathrm{~g} / \mathrm{d}$ (Whittemore et al. 1978). EUN output by pigs on dietary sequence LP-LP-LP did not decrease over the $32 \mathrm{~d}$ on test. This observation indicates that a reduction in the overall protein flux-rate in response to prolonged feeding of a diet low in $\mathrm{N}$ did not occur, and points instead to a swift-acting mechanism which would have reduced EUN output shortly after the introduction of diet LP (during the prefeeding period, days 1-7 of the experiment). Further evidence for such a mechanism was the reduction in urinary $\mathrm{N}$ output (and, hence, increase in $\mathrm{N}$ retention) in $7 \mathrm{~d}$ balance periods rather than $3 \mathrm{~d}$ balance periods in pigs changed from high to low $\mathrm{N}$ intake. During periods $2 \mathrm{~A}$ and $3 \mathrm{~A}$ pigs on sequences HP-LP-HP and LP-HP-LP had a mean urinary $\mathrm{N}$ output of 5.45 (SE 0.783$) \mathrm{g} \mathrm{N} / \mathrm{d}$ which was reduced by 0.33 in periods $2 \mathrm{~B}$ and $3 \mathrm{~B}$ to 3.67 (SE 0.046 ) $\mathrm{g} \mathrm{N} / \mathrm{d}$. Pigs on dietary sequences MP-LP-MP and LP-MP-LP curtailed their urinary $\mathrm{N}$ losses by the smaller margin of 0.11 between $3 \mathrm{~d}$ and $7 \mathrm{~d}$ on balance following the change to low- $\mathrm{N}$ intake $(4.19$ (SE 0.278$) \mathrm{g} \mathrm{N} / \mathrm{d}, 3-\mathrm{d}$ balances; 3.75 (SE 0.224) g N/d, 7-d balances). Therefore, the higher the dietary $\mathrm{N}$ intake before the change to low $\mathrm{N}$ intake, the greater the depression in $\mathrm{N}$ retention rate during the period immediately following the diet change-over, as also detected hitherto for pigs and rats by Holt et al. (1962) and Vaughan et al. (1962). The adjustment in urinary $N$ output to one commensurate with that following consumption of an $\mathrm{N}$-deficient diet might be attributed to a reduction in the proportion of the protein flux excreted as a consequence of the temporary shutdown of the urea cycle (Das \& Waterlow, 1974). In addition, there is evidence of increased re-utilization of amino acids (Nettleton \& Hegsted, 1975), so considerably extending protein half-life (Millward et al. 1976).

Enhanced $\mathrm{N}$ retention following $\mathrm{N}$ deficiency was due initially to the persistence of a curtailed urinary $\mathrm{N}$ excretion rate into a period of adequate $\mathrm{N}$ supply. In re-alimented rats, the contribution of the urea cycle to protein flux was fully restored within $2 \mathrm{~d}$ of the commencement of refeeding, but there was a $6 \mathrm{~h}$ lag following the change to higher protein intake before $\mathrm{N}$ excretion and the activity of urea-cycle enzymes began to rise (Das \& Waterlow, 1974). Similarly, refed infants maintained a low level of $N$ excretion during early re-alimentation (Picou \& Taylor-Roberts, 1969; Golden et al. 1977). The longer-term increased $\mathrm{N}$ retention rates exhibited by some pigs in the present study (sustained for $22 \mathrm{~d}$ in the case of sequence LP-HP-HP) might have been the outcome of enhanced efficiency of utilization of absorbed $\mathrm{N}$; this is consistent with the proposition that the pigs may have directed a higher proportion of $\mathrm{N}$ entering the metabolic pool to protein synthesis. Alternatively, or in addition, pigs given enhanced $\mathrm{N}$ supply may be capable of utilizing a greater range of $\mathrm{N}$-containing dietary constituents, such as the nucleic acid- $\mathrm{N}$ fraction in dried microbial cells, than those receiving a normal $\mathrm{N}$ supply.

The destination within the pig's body of $\mathrm{N}$ retained during enhanced supply remains uncertain. Slaughter trials with castrated male pigs fed to appetite (Tullis, 1981) suggested that daily $\mathrm{N}$ retention over the live-weight range used in this experiment averaged $18.3 \mathrm{~g}$, of which $8.8 \mathrm{~g}$ was deposited in the dissectable muscle mass. Mean daily $\mathrm{N}$ retentions on diets MP, HP and EP were $17 \cdot 1,22 \cdot 1$ and $32.0 \mathrm{~g}$ respectively. By extrapolation, pigs given diet EP would have deposited $200 \mathrm{~g}$ protein or $900 \mathrm{~g}$ lean daily, implying daily live-weight gains well in excess of $1 \mathrm{~kg}$, if depositions of water and fat were in the usual proportions. Actual daily live-weight gains by sequence EP-EP-EP pigs averaged $0.686 \mathrm{~kg}$. Nevertheless, increases in $\mathrm{N}$ retention at higher than adequate $\mathrm{N}$ intakes have been shown to occur (Boorman, 1980); infants' response in $\mathrm{N}$ retention to unusually higher $\mathrm{N}$ intakes was 
achieved by a constant rate of protein synthesis in conjunction wth a retarded rate of protein breakdown (Golden et al. 1977). The demonstration of the compensating response by pigs given diet EP (sequence LP-EP-EP) suggests that this phenomenon is associated with the replenishment of labile $\mathrm{N}$ stores within the pig's body, reinforced by the observation that on this treatment the compensatory response gradually disappeared, presumably as $\mathrm{N}$ stores became replete. The principal anatomical locations of labile $\mathrm{N}$ stores are unlikely to be skeletal muscle, which is relatively protected during dietary $\mathrm{N}$ deprivation, and are more likely to comprise the viscera, skin and plasma, which undergo reduction in protein mass during periods of $\mathrm{N}$ deprivation (Mendes \& Waterlow, 1958; Norton \& Walker, 1971; Garlick et al. 1973).

The financial support of Impe:ial Chemical Industries Ltd, Jealott's Hill, Berks, is gratefully acknowledged. The authors are also indebted to the staff of the Pig Unit and Central Analytical Laboratory of the Edinburgh School of Agriculture. J. B.T. was in receipt of a scholarship from the Ministry of Agriculture, Fisheries and Food.

\section{REFEREN CES}

Armstrong, D. G. \& Mitchell, H. H. (1955). Journal of Animal Science 14, 49-68.

Boorman, K. N. (1980). In Protein Deposition in Animals, pp. 147-166 [P. J. Buttery and D. B. Lindsay, editors]. London: Butterworths.

Das, T. K. \& Waterlow, J. C. (1974). British Journal of Nutrition 32, 353-373.

D'Mello, J. P. F., Peers, D. G. \& Whittemore, C. T. (1976). British Journal of Nutrition 36, 403-410.

Fowler, V. R. (1976). In Meat Animals: Growth and Productivity, pp. 285-299 [D. Lister, D. N. Rhodes, V. R. Fowler and M. F. Fuller, editors]. London: Plenum Press.

Garlick, P. J., Millward, D. J. \& James, W. P. T. (1973). Biochemical Journal 136, 935-945.

Golden, M. H. N., Waterlow, J. C. \& Picou, D. (1977). Clinical Science and Molecular Medicine 53, 473-477.

Holt, L. E., Halac, E. \& Kajdi, C. N. (1962). Journal of the American Medical Association 181, 699-705.

Mendes, C. B. \& Waterlow, J. C. (1958). British Journal of Nutrition 12, 74-88.

Millward, D. J., Garlick, P. J., James, W. P. T., Sender, P. \& Waterlow, J. C. (1976). In Protein Metabolism and Nutrition, pp. 49-69 [D. J. A. Cole, K. N. Boorman, P. J. Buttery, D. Lewis and H. Swan, editors]. London:

Butterworths.

Nettleton, J. A. \& Hegsted, D. M. (1975). Nutrition and Metabolism 18, 31-40.

Norton, B. W. \& Walker, D. M. (1971). British Journal of Nutrition 26, 7-13.

Picou, D. \& Taylor-Roberts, T. (1969). Clinical Science and Molecular Medicine 36, 283-296.

Tullis, J. B. (1981). Protein growth in pigs. PhD Thesis, Edinburgh.

Vaughan, O. W., Filer, L. J. \& Churella, H. (1962). Pediatrics 29, 90-96.

Whiting, F. \& Bezeau, L. M. (1957). Canadian Journal of Animal Science 37, 95-105.

Whittemore, C. T., Tullis, J. B. \& Hastie, S. W. (1978). British Journal of Nutrition 39, 193-200. 